\title{
Reseña de Mattza Su, Carmela V., La vida es sueño como speculum reginae: Isabel de Borbón en la corte de Felipe IV, Madrid, Verbum, 2017, 198 pp., ISBN: 978-84-9074-568-7
}

\section{Robin Ann Rice}

Universidad Popular Autónoma del Estado de Puebla (UPAEP)

MÉXICO

robinann.rice@upaep.mx

[Hipogrifo, (issn: 2328-1308), 6.2, 2018, pp. 833-835]

Recibido: 13-08-2018 / Aceptado: 17-09-2018

DOI: http://dx.doi.org/10.13035/H.2018.06.02.58

La vida es sueño como speculum reginae: Isabel de Borbón en la corte de Felipe IV de Carmela Mattza Su (Verbum, 2017), presenta un estudio meticuloso sobre la retórica y el contenido del saludo de Astolfo a Estrella (vv. 485-494) en la Vida es sueño de Calderón de la Barca. Dicha salutación revela a una Estrella que constituye un speculum reginae, que ilustra las expectativas de la época respecto de la actuación de la reina Isabel de Borbón, primera esposa de Felipe IV. El estudio inicia con una comparación de las dos versiones de la comedia en cuanto al papel de Estrella y su adhesión a los manuales más importantes en la época sobre la conducta femenina. Cuando Astolfo saluda a Estrella, la compara con tres figuras de la mitología clásica: Flora, Aurora y Palas, que simbolizaban las virtudes emblemáticas de la reina Isabel, según el material literario y visual de los ritos funerarios rendidos en su honor en 1644.

Tras una discusión detallada de distintas ediciones de la obra, se confirma el consenso global de que habría sido compuesta alrededor de 1630, lo cual contrasta con la falta de documentación sobre una posible representación en palacio ante Felipe IV e Isabel de Borbón, pese a un acuerdo entre los expertos respecto de que la obra se estrenó entre 1631 y 1636. Estrella es el reflejo ideal de la realeza femenina, aunque es uno de los personajes con el menor número de intervenciones y que la crítica ha apenas estudiado. Por ejemplo, cuando Estrella le declara a Basilio: «Pues yo al lado del sol seré Belona» (v. 2488), hace referencia a la imagen del Sol que representaba tanto a Felipe IV como a Felipe III. Por el otro lado, insiste Mattza, el comportamiento de Estrella está modelado según los preceptos de los manuales sobre la conducta femenina, como los de Juan Luis Vives, Juan de Pineda y fray 
Luis de León. Los intercambios de Estrella con los protagonistas como Astolfo o Segismundo están siempre marcados por su recato y control verbal.

Se subraya la importancia de Estrella por medio de la invocación a la diosa griega Palas, durante su intercambio con Basilio, que forma «un texto que cumple no solo una función retórica, sino también emblemática [...] cuyo significado no compete únicamente al campo de la moral [...] sino también al del arte pictórico y la política» (p. 64). Más significativo es el saludo de Astolfo a Estrella nombrando las tres deidades: Palas, Flora y Aurora, y su relación con el arte pictórico, con la política de la época y con la creación de un speculum reginae conceptual en La vida es sueño. La mención de Flora invoca las imágenes mentales de la Flora ovidiana o la de Boticelli, perseguida por un galán tal como Estrella por Astolfo o Segismundo. Flora también alude al concepto de la «Flor de Lis», asociada directamente con Isabel de Borbón. Por cuanto a la mención de Aurora en la salutación, Mattza advierte la relación con Isabel de Borbón: desde su primera entrada a Madrid, Isabel de Borbón es recibida como Aurora; incluso, existen materiales iconográficos que establecen tal vínculo. Por otra parte, equipar a Estrella con Palas denota una nueva manera de representar la autoridad y el poder en los tiempos de Isabel, y expresan los atributos de sabiduría y prudencia, que son las virtudes femeninas cortesanas.

El saludo de Astolfo da una nueva importancia a Estrella en la obra porque las «comparaciones con Flora, Aurora y Palas hacen de Estrella no sólo una figura de autoridad dentro de la obra, sino también fuera de ella, porque esas alusiones apuntan a una persona histórica concreta: la reina Isabel de Borbón» (p. 103). El trato metafórico de Isabel se aprecia más en sus funerales, que se conmemoraron en todo el imperio español. Además, Mattza Su demuestra que Estrella es un verdadero speculum reginae en cuanto a la conducta esperada de la mujer en poder. Destaca también que la falta de estudios dedicados a Estrella en la obra de Calderón se corresponde con la escasez de exámenes sobre Isabel de Borbón en cuanto a la política del Rey Planeta. Las exequias para la reina, muerta de erisipela en 1644, se desvían de los modelos establecidos por la casa de los Habsburgo a causa del papel de la Flor de Lis en asuntos políticos, que propició un desempeño favorable en tiempos de crisis. ¿Cuáles características subrayó la iconografía funeraria? En general, exaltaron una reina piadosa, «prudente y sabia en los asuntos del gobierno» (p. 107). En su relación de los funerales de la soberana, Antonio de León Pinelo modeló una figura santa, tal vez en seguimiento del ejemplo de la reina Isabel de Portugal, quien, ya muerta, se convirtió en santa Isabel. Por medio de un análisis de las conmemoraciones internacionales de la difunta, tales como Valladolid, Lima, Nápoles, Santo Domingo o Puebla de los Ángeles, el estudio desmenuza las figuras mitológicas e iconográficas en ellas que atan más estrechamente la imaginería de Estrella como futura reina, y la de la fallecida Isabel de Borbón. El hilo conductor que conecta las dos imaginerías - Estrella en La vida es sueño e Isabel de Borbón en vida pero especialmente en la muerte- es la mitografía de Flora, Aurora y Palas.

La mayoría de los estudios sobre las consortes de Felipe IV se dedica a su segunda esposa, Mariana de Austria. Por ello, es importante este análisis de Isabel. Durante dos décadas, la reina se ocupó de actividades cruciales de la administra- 
ción gubernamental, y gracias a ella pudo deshacerse del polémico conde-duque de Olivares. Como Aurora, la luz de la mañana, acompañaba a Felipe IV, el Sol. Al final del libro, Mattza recalca que la obra funciona como un speculum pero en el sentido pedagógico, ideal. El comportamiento de Estrella es un modelo, es decir, es belleza y luz en tiempos de paz, tal como en momentos bélicos sabe actuar. Así que Estrella refleja el comportamiento ideal de una reina. El texto ofrece un examen cuidadoso y creativo tanto de Estrella en La vida es sueño como de Isabel de Borbón y su papel como Flora, Aurora y Palas.

Mattza Su hace una revisión de las obras calderonianas con referencias a la primera esposa de Felipe IV. Entre éstas, menciona las siguientes: Mañanas de abril (1637) con referencias directas e indirectas a su belleza, las Indias Orientales y Occidentales, los jardines del Buen Retiro, la Corte de Madrid; El sitio de Breda (1626); Casa con dos puertas (1625), que repite menciones de Flor de Lis tal como hace El jardín de la Falerina. También existen obras que juegan con algunas de las diosas mitológicas como Flora y Aurora, ejemplificadas en El mayor monstruo del mundo (1636) y Los dos amantes del cielo (1636).

En La vida del sueño existe un speculum, pero no «es un espejo en su sentido tradicional, sino en uno distinto, porque la comedia no busca mimetizar a los reyes ni reflejar de manera fidedigna una imagen ya existente [...] [sino que] busca ofrecer una imagen ideal del comportamiento que aquellos que tienen a su cargo el gobierno de un reino deberían observar» (p. 179). En este libro, cuidadosamente investigado y documentado, Carmela Mattza Su ilumina dos personajes femeninos - uno ficticio y uno real-, cuya importancia ha sido escatimada, y les atribuye un significado mucho más profundo por medio de redes de asociaciones creadas por la mitología, la iconografía y la imaginería de la época. Así, Estrella representa un modelo ahormado por los manuales de conducta femenina de la época e idealizada por la mitología neoplatónica renacentista, que sirven como un emblema de la reina perfecta, en este caso, Isabel de Borbón. 